\title{
Wpływ języka włoskiego na obecny kształt języka molizańskich Chorwatów
}

\author{
Krzysztof Feruga \\ Akademia Techniczno-Humanistyczna, Wydziat Humanistyczno-Społeczny, \\ Ul.Willowa 2,PL-43-309 Bielsko-Biała,kferuga@ath.bielsko.pl
}

\begin{abstract}
SCN II/2 [2009], 94-99
Sobivajoči narodi in njihovi jeziki se ne morejo izogniti vzajemnim stikom, niti sporazumevalnim. To je vzrok za različne interference $\mathrm{v}$ lastnem in tujem jezikovnem sistemu. Leksikalnih izposojenk je v vsakdanjem govoru moliških Hrvatov zelo veliko. Njihova raba je odvisna predvsem od uporabnikovih namenov. Govorci poskušajo pri sporazumevanju s starejšimi prilagoditi besedišče obema jezikoma, z mlajšimi ali z vrstniki pa večinoma uporabljajo italijanščino. V prispevku je predstavljen tudi način, kako moliški Hrvati rešujejo težave z novimi besedami, vezanimi na razvoj tehnike, kulture in civilizacije.
\end{abstract}

Neighbouring nations and their languages cannot avoid mutual contacts, including communication contacts, which lead to different interferences in their own and the other language systems. There are huge numbers of lexical language borrowings in the common speech of Molise Croats that depend on the invention of the interlocutors. They try to adjust their lexis to both languages when they communicate with elder people, whereas they use Italian when they talk to their peers or to young people. This paper shows how Molise Croats cope with new vocabulary connected with development of technology, culture and civilization.

Ključne besede: moliški Hrvati, jezikovni sistem, izposojanje, klišeji

Key words: Molise Croats, language system, transfers, borrowings

Narody i ich języki kohabitujące ze sobą nie mogą uniknąć wzajemnych kontaktów, w tym komunikacyjnych, co doprowadza do rozmaitych interferencji we własnych i obcych systemach językowych. Dochodzi więc do zapożyczeń, kalek itp. Szczególnie narażone są na tego typu wpływy języki, które osłabiły lub utraciły kontakt z własną macierzą. Język molizańskich Chorwatów należy właśnie do najlepszych przykładów obrazujących taką sytuację. 
Historyczne analizy wskazują na fakt, iż przodkowie dzisiejszych molizańskich Słowian przybyli do południowych Włoch na przełomie XV i XVI wieku z Dalmacji, z terenów pomiędzy rzekami Cetinią i Neretwą, a dokładniej z obszarów ich ujścia do Adriatyku (Rešetar 1997: 33-37). Przypuszcza się, iż do samego Molise wyemigrowało wtedy kilka tysięcy Chorwatów (Scotti 2006: 16), którzy zasiedlić mieli tam około 15 wiosek (Piccoli 1999: 100).

Od momentu przybycia Słowian na nowe tereny osiedleńcze w środkowopołudniowej części Włoch ich język rozwijał się w specyficznych warunkach i okolicznościach, skutecznie izolowany od macierzy, w najbliższym, niesłowiańskim sąsiedztwie. Był więc narażony na intensywne procesy dezintegracyjne, tracąc z czasem wiele elementów rodzimych, począwszy od poziomu fonetyczno-fonologicznego przez morfologiczny po syntaktyczny i przede wszystkim leksykalny. Zachowano więc wiele cech dawnego języka starochorwackiego, którym posługiwali się przodkowie molizańskich Chorwatów, jeszcze przed przesiedleniem się w regiony południowych Włoch, a także języków włoskiego i abruzyjsko-molizańskiego. Język był przekazywany z pokolenia na pokolenie tradycją mówioną i dopiero na przełomie XX i XXI wieku zauważyć można zintensyfikowaną działalność normatywną.

Molizańscy Chorwaci zamieszkują obecnie już tylko 3 wioski w południowo-wschodnim włoskim regionie Molise: Acquaviva Collecroce (m-ch. Živavoda Kruč), San Felice del Molise (m-ch. Filič lub Stifilič) i Montemitro (m-ch. Mundimitar). Sa to dawne osiedla obronne usytuowane na pobliskich wzgórzach łańcucha apenińskiego, oddalone od siebie o kilkanaście kilometrów na wysokości 200-700 m. nad poziomem morza. Teren ten leży między dwoma rzekami Trigno i Biferno, około $20 \mathrm{~km}$. od wybrzeża Adriatyckiego (port Termoli). Stolicą prowincji jest Campobasso (Kampavaša). Sam region Molise został niedawno utworzony, powstał w 1963 r. z części terytorium regionu Abruzzo i należy do dość ubogich prowincji włoskich.

W chwili obecnej ludności mówiącej na našo, językiem molizańskochorwackim, trudno jest jednoznacznie określić. Według oficjalnego spisu ludności z 1991 roku Słowian Molizańskich / Chorwatów Molizańskich było 2. 322 (Piccoli 1999: 71). Obecnie nikt podobnej statystyki nie prowadzi. Sądzi się, że żywą aktywność językową można spotkać u około 2.000 mieszkańców. Wynika to z ich sytuacji społecznej. Na terenie tych trzech miejscowości nie prowadzi się nieomalże żadnej poważnej działalności gospodarczej. Starsza ludność żyje z niewielkich emerytur lub rent, trudniąc się jednocześnie rolnictwem (uprawa oliwek, winnej latorośli i zbóż), zaś aktywni zawodowo dojeżdżają do pobliskich miasteczek (Termoli, San Salvo, i in.), młodzież zaś jest zmuszona kształcić się w szkołach ponadpodstawowych i wyższych poza swoim miejscem zamieszkania. Wiąże się to ze znacznym odpływem ludności wiekowo stosunkowo młodej, dochodzi do częstych małżeństw mieszanych, a współczesny styl życia, instytucje wyznaniowe, szkolnictwo, urzędy i media, których językiem był i jest język włoski, mające od wieków ogromny wpływ na system komunikacyjny molizańskich Chorwatów, oraz bilingwizm wszystkich mieszkańców, czynią wielkie spustoszenia w tożsamości, szczególnie wśród młodych ludzi. 
Enklawa słowiańska, zamknięta najpierw w obronnych murach na wzgórzach apenińskich, była hermetyczna i kultywowała właściwie bez przeszkód swoje tradycje. Z biegiem lat, wraz z rozwinięciem się struktur przemysłowych, komunikacyjnych i społecznych, molizańscy Chorwaci coraz częściej ulegali kontaktom z ludnością włoską. Coraz częściej w swej codziennej komunikacji wspierają się standardem włoskim i jego okolicznymi dialektami zapożyczając bez ograniczeń wszystkie elementy na wszystkich poziomach języka. A. Piccoli i A. Sammartino zbierając materiał leksykalny do swojego słownika (Piccoli, Sammartino 2000: XXII-XXIII) stwierdzili, iż pożyczki, głównie włoskie i abruzzyjskie dotyczą określonych dziedzin życia słowiańskich mieszkańców regionu Molise. Właściwie, to już ich poprzednicy, m.in. J. Smodlaka, M. Rešetar, zajmujący się językiem molizańsko-chorwackim na fakt ten zwracali uwagę. Najwięcej zapożyczeń można spotkać na poziomie leksyki, a dotyczą one np. nazw miesięcy, określenia stopnia pokrewieństwa, liczebników itp.

Nazwy miesięcy:

\begin{tabular}{|c|l|l|l|}
\hline & m-ch. & wł. & ch. \\
\hline 1. & jenara & gennaio & siječanj \\
\hline 2. & frebara & febbraio & veljača \\
\hline 3. & marca & marzo & ožujak \\
\hline 4. & abrila & aprile & travanj \\
\hline 5. & maja & maggio & svibanj \\
\hline 6. & džunja & giugno & lipanj \\
\hline 7. & lulja & luglio & srpanj \\
\hline 8. & agušta & agosto & kolovoz \\
\hline 9. & sutembra & settembre & rujan \\
\hline 10. & atubra & ottobre & listopad \\
\hline 11. & novembra & novembre & studeni \\
\hline 12. & dučembra & dicembre & prosinac \\
\hline
\end{tabular}

Ludność słowiańska z języka włoskiego zaczerpnęła określenia nazw miesięcy, jednakże nazwy dni tygodnia pozostały rodzime, np. m-ch. jutorak, ch. utorak; m-ch. petak, ch. petak itd.

Liczebniki (Sammartino 2004: 247):

\begin{tabular}{|l|l|l|l|}
\hline & m-ch. & wł. & ch. \\
\hline 1 & un/jena & uno & jedan \\
\hline 2 & du/dva & due & dva \\
\hline 3 & tre/tri & tre & tri \\
\hline 4 & kuatr/četir & quattro & četiri \\
\hline 15 & kuinič/petnast & quindici & petnaest \\
\hline 19 & dičanov/devetnast & diciannove & devetnaest \\
\hline 23 & vinditre/dvadeset tri & ventitre & dvadeset tri \\
\hline 30 & trenda/trideset & trenta & trideset \\
\hline 40 & kuaranda/četirdeset & quaranta & četrdeset \\
\hline 50 & činguanda/petdeset & cinquanta & pedeset \\
\hline
\end{tabular}


Formy pochodzące z języka włoskiego są częściej używane, niż formy słowiańskie. Molizańscy Chorwaci posługują się najczęściej formami słowiańskimi w zakresie od 1-5, do wyrażania pozostałych liczebników używają głównie zaadaptowanych do swoich potrzeb form włoskich, np.

ch. tri dana, m-ch. tri dana; ch. deset dana, m-ch. diječ dana, itd.

Część włoskich wyrazów została zeslawizowana. Również w formach gramatycznych spotkać możemy wpływy języka włoskiego, które widoczne są głównie we wspomnianych już formach liczebnikowych, w sposobie stopniowania przymiotników, ale również w leksyce. Przykładów jest wiele, np. przy określaniu stopnia pokrewieństwa część wyrazów jest pochodzenia chorwackiego, a część włoskiego:

m-ch. otac, ch. otac;

m-ch. mat, ch. majka;

ale już

m-ch. tarela, ch. djed; m-ch. marela, ch. baka, itp.

Taljanizmy obecne są także w formach gramatycznych języka molizańskich Chorwatów, w szczególności w I i IV koniugacji czasowników (Sammartino 2004: 254-256). Do pierwszej koniugacji należy szereg czasowników pochodzenia włoskiego, zakończonego na -are. Czasowniki te w języku molizańskochorwackim w bezokoliczniku kończą się na -at, np.:

- rivat (wł. arrivare, ch. doći)

- nduvinat (wł. indovinare, ch. pogoditi)

- tokat (wł. toccare, ch. taknuti, dodirnuti)

Bezookolicznik czasowników IV koniugacji kończy się na -it. Podobnie, jak przy pierwszej koniugacji, i tu możemy spotkać wiele czasowników pochodzenia włoskiego, które zakończone są na -ere i -ire, np.:

- premit (wł. premere, ch. pritisnuti)

- akapit (wł. capire, ch. razumjeti)

- dečidit (wł. decidere, ch. odlučiti)

Na wzór języka włoskiego przyswojony został sposób wyrażania przysłówków w odniesieniu do faktu, iż czegoś jest mniej. W języku włoskim używamy wtedy sufiksu -ino, w jęz. m-ch. sufiksu -ico, np.:

- malo (ch. malo) - malico (ch. nešto malo)

- dobro (ch. dobro) - dobrico (ch. dosta dobro)

- grubo (ch. ružno) - grubico (ch. dosta ružno)

Istnieje także szereg przysłówków, które zostały utworzone poprzez dodanie włoskiego sufiksu -mente, który uległ zeslawizowaniu, np.:

- finalmend (ch. konačno)

- siguramend (ch. sigurno)

- čertamend (ch. jamačno) 
Zapożyczeń leksykalnych w języku molizańsko-chorwackim są ogromne ilości i zależą one od inwencji rozmówców. W komunikacji z osobami starszymi rozmówcy starają się dostosowywać swój zasób leksykalny do obu języków, z osobami młodszymi lub rówieśnikami przechodzi się najczęściej na język włoski, który coraz bardziej wypiera język molizańsko-chorwacki.

Obecnie, wprowadzając nowy zasób słownictwa do języka molizańskich Chorwatów, związany np. ze współczesnym rozwojem cywilizacyjnym, powstawaniem nowych dziedzin nauki, nowych przedmiotów, urządzeń, zawodów itp., używa się głównie słownictwa włoskiego, rzadko tworzone są nowe terminy zaczerpnięte $\mathrm{z}$ języka chorwackiego. Związane to jest z tym, iż Słowianie w Molise na co dzień używają języka włoskiego, oglądają włoską telewizję, czytają włoskie gazety itd. Dostęp do macierzy nadal nie należy do prostych, pomimo tego, iż w Mundimitrze swoją placówkę ma Honorowy Konsul Chorwacji. Prowadzone są różne akcje mające na celu utrzymanie kontaktów z językiem chorwackim: wydawane są różne publikacje w języku chorwackim i molizańsko-chorwackim, organizowane są wystawy, przeglądy itp. Stanowi to jednakże kroplę wody w morzu potrzeb. Język włoski coraz bardziej wpływa na molizańskich Chorwatów, którzy oprócz nowego słownictwa, które powstaje, a które to czerpią ze standardu włoskiego, często także w codziennych rozmowach na-našo nie znając bądź zapominając niektóre słowa, posiłkują się językiem włoskim, częstokroć nie wracając już w rozmowie do języka molizańsko-chorwackiego.

Jak już wcześniej wspomniano, region ten należał i nadal należy do grupy najuboższych w całych Włoszech. Z tego powodu, głównie ludzie młodzi, nie widząc żadnych mozliwości na poprawę warunków życia w molizańskich wioskach, opuszczają domy rodzinne emigrując, przeważnie do większych miast włoskich, w poszukiwaniu lepszych możliwości zarobkowych i życiowych. Migrując w inne regiony włoskie, Chorwaci przestają posługiwać się językiem, którego nauczyli się w domach rodzinnych. A w związku z faktem, iż są bilingwalni, nie mają większych problemów w odnalezieniu się we włoskiej rzeczywistości. Część z nich nie zapomina jednakże o swoich korzeniach: ich znajomość języka molizańsko-chorwackiego z czasem ulega coraz większej italianizacji.

\section{BIBLIOGRAFIA}

Walter BREU, Giovanni PICCOLI, 2000: Dizionario croato molisano di Acquaviva Collecroce. Dizionario plurilingue della lingua slava minoranca di provenienza dalmata di Acquaviva Collecroce in Provincia di Campobasso, dizionario, registri, grammatica, testi. Campobasso.

Krzysztof FERUGA, Emil TOKARZ, 2007: Świat południosłowiańskich diaspor na przykładzie Molizańskich Słowian. Świat Techniki i Humanistyki. Prace Nau- 
kowe Akademii Techniczno-Humanistycznej nr 1. Red. E. Tokarz. Wydawnictwo Naukowe ATH. Bielsko-Biała, 213-216.

Agostina PICCOLI, 1995: Fonološki prikaz govora u Montemitru. Hrvatska Obzorja, 4/1995, 877-896.

Agostina PICCOLI, 1996: Govor moliških Hrvata. Tjedan moliških Hrvata. Hrvatska Matica Iseljenika. 16.-21. 06. 1996. Zagreb, 29-32.

Agostina PICCOLI, 1999: Ali tagliate. Parole di un libro incompiuto. Vasto.

Agostina PICCOLI, Antonio SAMMARTINO, 2000: Dizionario dell'idioma croatomolisano di Montemitro / Rječnik moliškohrvatskoga govora Mundimitra. Fondazione „Agostina Piccoli”. Montemitro-Zagreb: Matica Hrvatska.

Milan REŠETAR, 1997: Le colonie serbocroate nell'Italia meridionale. Tłumaczenie na j. włoski: W. Breu i M. Gardenghi. (oryginał w j. niemieckim: Die Serbokroatischen Kolonien Süditaliens. Wien 1911). Dodatkowe notatki i bibliografia. Campobasso.

Antonio SAMMARTINO, 2004: Grammatica della lingua Croatomolisana / Gramatika moliškohrvatskoga jezika. Fondazione „Agostina Piccoli”. Montemitro-Zagreb: Profil International.

Giacomo SCOTTI, 2006: Hrvatski trokut u Italiji. Rijeka: Liber.

Tjedan moliških Hrvata. Zagreb: Hrvatska Matica Iseljenika. 16.-21. 06. 1996.

\section{VPLIV ITALIJANŠČINE NA SODOBNI JEZIK MOLIŠKIH HRVATOV}

Sobivajoči narodi in njihovi jeziki se ne morejo izogniti vzajemnim stikom, niti sporazumevalnim. To je vzrok za različne interference $\mathrm{v}$ lastnem in tujem jezikovnem sistemu. Prihaja do prevzemanja, klišejev itd. Takim vplivom so še posebej izpostavljeni jeziki, ki so povsem izgubili stike $z$ matico ali pa je njihov stik vedno šibkejši. Jezik moliških Hrvatov je zelo dobra ponazoritev opisane situacije.

Prispevek poskuša pokazati vpliv italijanskega jezika na jezik moliških Hrvatov, ki trenutno naseljujejo le tri vasi jugovzhodne Italije: Acquaviva Collecroce (Živa voda Kruč), San Felice (Filič) in Montemitro (Mundimitar). V vsakdanji komunikaciji vse pogosteje uporabljajo italijanščino in njene okoliške dialekte ter si tako izposojajo številne elemente na vseh jezikovnih ravninah. Veliko prevzetih besed in klišejev, pretežno italijanskih in iz jezika Abrucov, se nanaša na določena področja slovanskih prebivalcev italijanske regije Molise. Največ jih najdemo na leksikalni ravni, in sicer za poimenovanja sorodstvenih razmerij, števnikov, imen mesecev ipd.

Leksikalnih izposojenk je v vsakdanjem govoru moliških Hrvatov zelo veliko. Njihova raba je odvisna predvsem od uporabnikovih namenov. V sporazumevanju s starejšimi poskušajo govorci prilagoditi besedišče obema jezikoma, z mlajšimi ali z vrstniki pa večinoma uporabljajo italijanščino.

$\mathrm{V}$ prispevku je predstavljen tudi način, kako moliški Hrvati rešujejo težave z novimi besedami, vezanimi na razvoj tehnike, kulture in civilizacije. 